\title{
Vegetative Propagation of Argania spinosa (L.) Skeels Cuttings: Effects of Nutrient Solution
}

\author{
A. Benbya ${ }^{1,2}$, M. Mdarhri. Alaoui ${ }^{*}$, F. Gaboun ${ }^{1}$, F. Delporte 3 , S. Cherkaoui ${ }^{2}$ \\ ${ }^{1}$ Biotechnology Unit, Regional Center of Agricultural Research of Rabat, National Institute of Agronomy Research of \\ Morocco (INRA), P.O. Box 6570, Rabat Institutes, Rabat, Morocco. \\ 2 Physiology and Biotechnology Laboratory, Department of Biology, Faculty of sciences (FSR), Mohamed V University, \\ P.O. Box 1014, Rabat, Morocco. \\ ${ }^{3}$ Department of Life Sciences, Bioengineering Unit, Walloon Agricultural Research Centre (CRA-W), Chaussée de Charleroi \\ 234, P.O. Box 5030, Gembloux, Belgium. \\ Corresponding author. E-mail: meriem.malaoui@gmail.com, Phone number: +212 666624428 . \\ BP 813710102 Nations UNIES Agdal Rabat Morocco.
}

\begin{abstract}
The effects of the mineral composition of nutrient solution (Hoagland and Arnon (HA), Quoirin and Lepoivre (QL), Murashige and Skoog (MS), and Woody Plant Medium (WPM)), cutting type (softwood, semi-hardwood and hardwood) and cutting position (basal, medial, and apical) on sprouting and rooting performance of Argania spinosa cuttings were investigated. According to the results, the nutrient solution, cutting type and cutting position had an effect on the sprouting and adventitious rooting ability of $A$. spinosa cuttings. The leafy semi-hardwood cuttings taking from the basal positions and irrigated with Hoagland solution performed best and produced the highest number of roots (44.63), root length $(28.86 \mathrm{~cm})$, and had the highest rooting and survival percentage $(63.81 \%$ and $96.09 \%$, respectively). The nutrient solution applications caused a notable increase in sprouting and rooting potential of the argan tree. The highest values were recorded for HA and QL, while the MS and WPM gave the poorest result and the greatest mortality rate of cuttings.
\end{abstract}

The cuttings type had also a pronounced effect on vegetative propagation of A. spinosa. The leafy semihardwood cuttings performed better than the leafy softwood cuttings, whereas leafless hardwood cuttings were completely unable to sprout and root even when treated with nutrient solutions. Thus, vegetative propagation of A. spinosa can best be achieved using basal leafy semi-hardwood cuttings irrigated with Hoagland nutrient solution.

Keywords-Argania spinosa, cutting, nutrient solution, rooting, vegetative propagation.

\section{INTRODUCTION}

Argania spinosa $(L$.$) , commonly known as the argan tree,$ is a thorny evergreen tree. Its main natural distribution extent is limited to the south-west of Morocco, from the Atlantic coast and Souss plains to bordering slopes of the
Anti-Atlas and High Atlas mountains, between Oued Tensift to the north and Oued Draa to the south (Emberger 1925; Msanda, 1993). The argan forest is recognised by UNESCO since 1998 as a biosphere reserve with a rich natural biodiversity. It's an indispensable component of the ecological balance of semi-arid south-western ecosystems of Morocco (Msanda et al., 2005). In fact, A. spinosa is recommended as a climate change mitigation species because it acts as a barrier against desertification, protects the soil against erosion, retains water moisture, restores soil fertility and provides a very favorable area for intercropping or fallow management by its deep root system (Morton and Voss, 1987; M'hirit et al., 1998). The argan tree is still reproduced through seeds but does not guarantee the production of a high-performance material. Although the seeds can germinate readily, the gradual destruction of the argan forest coupled with unsustainable seeds harvesting methods, overgrazing and the reconversion of the argan woodland into intensive agriculture systems are posing an increasing threat to natural regeneration, reducing the population size, and could result in fewer individuals of this species (Nouaim et al., 2002). Therefore, an alternative method such as clonal propagation is required for mass multiplication of elite genotypes obtained in breeding programs or selected from natural populations (Hartmann et al., 1997). Compared to other vegetative propagation techniques, the use of cuttings is considered as the most efficient and low-cost method (Leakey, 2004). It's an efficient method for producing large numbers of uniform plants, but it does not always succeed due to some difficulties of rooting and subsequent growth that can be observed (De Vries and Dubois, 1988; Dubois and De Vries, 1991). The rooting potential of stem cuttings varies considerably among plant species, some can easily root while others remain recalcitrant even with the application of growth regulators (De Klerk et al., 1999). Rooting in stem cuttings of woody species is a complex 
process that is affected by a combination of physiological processes in the leaf and stem portions of the cuttings. Each of these processes is influenced by numerous morphological and anatomical factors which result from interactions with the genetic background, age, ontogenetic phase, culture conditions of the stock plant and postseverance treatments such as plant growth regulators and composition of the nutriment solution (Németh, 1986; Hartmann et al., 2002). Based on the species being propagated, the cutting maturity and a specific type of cutting are usually required. Some species root more easily with softwood, others require semi-hardwood cuttings, and still, others may root easier when hardwood cuttings are used (Greenwood and Hutchison, 1993; Hartmann et al., 2002). Moreover, adventitious root ability may vary between cuttings from different nodal positions, especially in woody species (Hansen and Kristensen, 1990; Bredmose et al., 2004). The position of the cutting on the stock plant affects the bud break and the shoot growth (Bredmose and Hansen, 1996; Husen and Pal, 2007; Otiende et al., 2017). The nutritional approach suggested that nutritional factors rather than growth substances are involved in regulating plant growth and development including rooting process (Fageria and Moreira, 2011). The metabolism of adventitious rooting is influenced by mineral nutrients of the stock plant or of its cuttings during propagation (Haissig, 1986). Indeed, the mineral nutrients are able to influence adventitious rooting, either by inhibiting or increasing the number of adventitious roots or by modulating the root length. Therefore, rooting may be increased if stock plants or cuttings are properly supplied with a combination of low to moderate amounts of other macro- or micro-nutrients ordinarily required for satisfactory plant vigour (Eliasson, 1978). This study was undertaken to investigate the influence of the mineral composition of the nutritive solution, cutting position and cutting type on sprouting and rooting ability of Argania spinosa cuttings.

\section{MATERIALS AND METHODS}

\section{Sources and preparation of cuttings}

Cuttings were collected from adult Argania spinosa trees from the Arboretum of Oued Cherat, province of Bouznika in Morocco (3381'96" N; 7¹1'03" W; $45 \mathrm{~m}$ altitude), which is located within $2000 \mathrm{~m}$ of the Moroccan Atlantic coast and with an average annual rainfall of 460 mm.yr ${ }^{-1}$. The selected trees were growing in wild conditions and showing superior phenotypes with very good crown diameter, fruits shape and caliber. Shoots were collected by using sterile pruning scissors from the tree crown in the early morning and were kept in perforated plastic bags inserted in a cool box to prevent drying during collection before being taken to the laboratory. Prior to insertion in the rooting medium, cuttings were stored in a dark cold room $\left(4^{\circ} \mathrm{C}\right)$ during 48 hours. The terminal node of the shoots was excised, then cuttings were excised and kept separately according to the position on the stock plant (basal, medial and apical), then they were classified with regard to cutting types. Actually, hardwood (leafless) cuttings were taken in winter. However, softwood (green and tender wood; leafy) cuttings were taken in spring and semi-hardwood (semilignified; leafy) cuttings were taken in summer. Healthy cuttings were screened to $(10 \pm 0.5) \mathrm{cm}$ length with at least six nodes. Leaves were excised from the down part so that only four leaves remained on the cuttings to minimize water stress caused by transpiration. To minimise fungal attacks, a chemical surface disinfection was applied on these cuttings for $10 \mathrm{~min}$ with a $0.2 \%$ (w/v) fungicide solution (Dithane-M45) and subsequently washed with sterile distilled water. The apical cut ends of the treated cuttings were sealed with tree wound dressings to reduce the water loss, prevent diseases and decay. The base of each cutting was wounded (basal cut just below a node), then it was soaked for $5 \mathrm{~min}$ in $3000 \mathrm{mg} . \mathrm{L}^{-1}$ of indole-3-butyric acid (IBA), this concentration proved to be the most successful in a study conducted by our team (currently being published). Prepared cuttings were immediately placed in $1000 \mathrm{cc}$ polyethylene (PE) pots containing sterilized sieved sand placed in greenhouse under the natural conditions of luminescence and humidity and a mean temperature of $32 \pm 2{ }^{\circ} \mathrm{C}$, at the biotechnology unit of the Regional Center of Agricultural Research of Rabat, INRA-Morocco. To harden the plants, rooted cuttings with roots of more than $1 \mathrm{~cm}$ long and without symptoms of fungal diseases were transferred to 4500 cc polyethylene (PE) pots containing a mix of sterilized sieved sand, sterilized forest soil and peat moss $(1: 1: 1 \mathrm{v} / \mathrm{v})$. These pots were then placed in the green house, at a spacing of $20 \mathrm{~cm} \times 20 \mathrm{~cm}$. The growing cuttings were monitored for a two year period. Cuttings were regularly watered every 2 days with tap water and received weekly applications of nutrient solution Hoagland and Arnon (HA; Hoagland and Arnon, 1950), Quoirin and Lepoivre (QL; Quoirin and Lepoivre, 1977), Murashige and Skoog (MS; Murashige and Skoog, 1962), and Woody Plant Medium (WPM; Lloyd and Mc Cown, 1980). The macronutrients were added separately from stock solutions. A combined stock solution is made up containing all micronutrients except iron. Iron is added as ferrous sulphate heptahydrate $\left(\mathrm{FeSO}_{4} .7 \mathrm{H}_{2} \mathrm{O}\right)$. The $\mathrm{pH}$ of the nutrient solution was adjusted to a value of $5.6 \pm 0.2$.

\section{Experimental design and treatments}

The experiment was organised according to a randomized complete block design (RCBD). Thirty two replications were used in four blocks for each treatment. The experiment tested three cutting types (leafy softwood (SW), leafy semi-hardwood (SHW) and leafless 
hardwood (HW) stem cuttings), three cutting positions (apical, medial and basal position), four nutrient solution treatments (Hoagland and Arnon (HA), Quoirin and Lepoivre (QL), Murashige and Skoog (MS), and Woody Plant Medium (WPM)) and their interactions.

\section{Data collection}

After 12 weeks, the cuttings were scored for the number of leaves (NL), leaf size in $\mathrm{cm}^{2}$ (LS), number of sprouts (NS), length of the longest sprout $\mathrm{cm}$ (SL), sprouting rate (SP \%), number of roots (NR), length of the longest root in $\mathrm{cm}(\mathrm{RL})$, and rooting rate (RP \%). Finally, the survival rate $(\mathrm{SR} \%)$ was recorded 48 weeks after rooting induction, a period that has been considered sufficient to measure the survival of rooted cuttings.

\section{Statistical analysis}

The data collected were submitted to tests of analysis of variance (ANOVA) for treatment effects of the general linear model (GLM) procedure in SAS program version 9.1 (SAS Institute, Cary, NC, USA) for all the evaluated parameters. Comparisons between treatments were performed by using Duncan's Multiple Range Test (DMRT) with at least $95 \%$ level of statistical reliance, and as a result, homogenous groups were acquired and interpreted. All data were reported as means \pm standard deviation (SD). Before statistical analysis, data were converted by angular transformation $(\mathrm{X}=\operatorname{arcsine} \sqrt{ } \mathrm{Y})$ for sprouting, rooting and survival ratios.

\section{RESULTS}

1. Effect of the nutrient solution, cutting type and position on the number of leaves and leaf size of Argania spinosa cuttings

\subsection{Number of leaves}

The highest number of leaves was obtained from hardwood cuttings, followed by the semi-hardwood cuttings, although softwood cuttings tended to produce the lowest result (Table 1). The lignification trend in the number of leaves was also similar for cutting position. Over the entire experimental period, basal position had a highest leaf number, followed by the medial position (Table 1). In our study, the highest number of leaves for basal hardwood cuttings was observed with MS solution (36.25 \pm 0.73), while softwood cuttings treated with WPM solution presented the lowest number of leaves and exhibited several nutrient-deficiency symptoms and chlorosis on their leaves.

\subsection{Leaf size}

Leaf size had a mean per cutting significantly greater in hardwood cuttings, followed by semi-hardwood then softwood cuttings (Table 1). The highest mean for leaf size was observed in cuttings taken from the basal position followed by cuttings of medial position then apical position (Table 1). The results presented herein indicate that leaf size of basal softwood cuttings treated with WPM or HA was generally lower $\left(9.90 \pm 0.46 \mathrm{~cm}^{2}\right.$ and $11.19 \pm 0.49 \mathrm{~cm}^{2}$, respectively) than that for basal hardwood cuttings irrigated with either QL or MS (24.96 $\pm 0.53 \mathrm{~cm}^{2}$ and $28.93 \pm 0.71 \mathrm{~cm}^{2}$, respectively).

The mean number of leaves and size were significantly $(\mathrm{P}$ $<0.01$ ) affected by the nutrient solution, cutting type and cutting position, while interactive effect of nutrient solution, cutting type and cutting position had a significant $(\mathrm{P}<0.01)$ effect only for leaves size (Table 2$)$.

Table.1: Effects of nutrient solution, cutting type and cutting position on mean values of the number of leaves (NL) and leaf size $\mathrm{cm}^{2}$ (LS) of Argania spinosa cuttings.

\begin{tabular}{|c|c|c|c|c|c|c|c|}
\hline \multirow[t]{2}{*}{ Nutrient solution } & \multirow[t]{2}{*}{ Cutting position } & \multicolumn{2}{|l|}{ SW } & \multicolumn{2}{|l|}{ SHW } & \multicolumn{2}{|l|}{ HW } \\
\hline & & NL & LS & NL & LS & NL & LS \\
\hline \multirow[t]{3}{*}{ HA } & Apical & $00.00 \pm 0.00^{c}$ & $00.00 \pm 0.00^{c}$ & $00.00 \pm 0.00^{\mathrm{d}}$ & $00.00 \pm 0.00^{\mathrm{g}}$ & $00.00 \pm 0.00^{d}$ & $00.00 \pm 0.00^{\mathrm{e}}$ \\
\hline & Medial & $00.00 \pm 0.00^{c}$ & $00.00 \pm 0.00^{c}$ & $21.38 \pm 0.89^{c}$ & $15.64 \pm 0.74^{\mathrm{de}}$ & $28.38 \pm 0.84^{c}$ & $19.35 \pm 0.65^{\mathrm{d}}$ \\
\hline & Basal & $17.50 \pm 0.75^{b}$ & $11.19 \pm 0.49^{b}$ & $22.00 \pm 0.59^{\mathrm{bc}}$ & $17.20 \pm 0.55^{\mathrm{cd}}$ & $29.31 \pm 0.73^{c}$ & $20.66 \pm 0.62^{d}$ \\
\hline \multirow[t]{3}{*}{ QL } & Apical & $00.00 \pm 0.00^{c}$ & $00.00 \pm 0.00^{c}$ & $00.00 \pm 0.00^{d}$ & $00.00 \pm 0.00^{\mathrm{g}}$ & $00.00 \pm 0.00^{d}$ & $00.00 \pm 0.00^{\mathrm{e}}$ \\
\hline & Medial & $00.00 \pm 0.00^{c}$ & $00.00 \pm 0.00^{c}$ & $24.00 \pm 0.75^{\mathrm{ab}}$ & $18.05 \pm 0.51^{b c}$ & $32.00 \pm 0.88^{b}$ & $23.36 \pm 0.56^{c}$ \\
\hline & Basal & $19.25 \pm 0.79^{\mathrm{a}}$ & $13.61 \pm 0.53^{\mathrm{a}}$ & $24.56 \pm 0.72^{\mathrm{a}}$ & $19.78 \pm 0.78^{\mathrm{ab}}$ & $32.75 \pm 0.64^{b}$ & $24.96 \pm 0.53^{\mathrm{bc}}$ \\
\hline \multirow[t]{3}{*}{ WPM } & Apical & $00.00 \pm 0.00^{c}$ & $00.00 \pm 0.00^{c}$ & $00.00 \pm 0.00^{\mathrm{d}}$ & $00.00 \pm 0.00^{\mathrm{g}}$ & $00.00 \pm 0.00^{\mathrm{d}}$ & $00.00 \pm 0.00^{\mathrm{e}}$ \\
\hline & Medial & $00.00 \pm 0.00^{c}$ & $00.00 \pm 0.00^{c}$ & $20.63 \pm 0.91^{c}$ & $13.66 \pm 0.60^{\mathrm{f}}$ & $27.19 \pm 1.32^{c}$ & $17.10 \pm 0.92^{\mathrm{d}}$ \\
\hline & Basal & $16.88 \pm 0.72^{b}$ & $09.90 \pm 0.46^{\mathrm{b}}$ & $21.62 \pm 0.86^{c}$ & $15.07 \pm 0.65^{\mathrm{ef}}$ & $28.94 \pm 0.86^{c}$ & $18.90 \pm 0.6 \mathrm{~d}^{\mathrm{c}}$ \\
\hline \multirow[t]{3}{*}{ MS } & Apical & $00.00 \pm 0.00^{c}$ & $00.00 \pm 0.00^{c}$ & $00.00 \pm 0.00^{\mathrm{d}}$ & $00.00 \pm 0.00^{\mathrm{g}}$ & $00.00 \pm 0.00^{\mathrm{d}}$ & $00.00 \pm 0.00^{\mathrm{e}}$ \\
\hline & Medial & $00.00 \pm 0.00^{c}$ & $00.00 \pm 0.00^{c}$ & $24.50 \pm 0.70^{\mathrm{a}}$ & $20.18 \pm 0.71^{\mathrm{a}}$ & $33.19 \pm 0.75^{b}$ & $25.47 \pm 0.62^{b}$ \\
\hline & Basal & $20.19 \pm 0.83^{a}$ & $14.71 \pm 0.69^{\mathrm{a}}$ & $25.31 \pm 0.56^{\mathrm{a}}$ & $21.49 \pm 0.51^{\mathrm{a}}$ & $36.25 \pm 0.73^{\mathrm{a}}$ & $28.93 \pm 0.71^{\mathrm{a}}$ \\
\hline
\end{tabular}

Within each treatment, value marked by the same letter are not significantly different (Duncan's Multiple Range Test $(D M R T), P<0.05$, mean $\pm S D, n=32)$. 
Table.2: Analysis of variance (ANOVA) for effect of nutrient solution, cutting type, cutting position and their interactions on the number ofleaves and leaves size $\left(\mathrm{cm}^{2}\right)$ of Argania spinosa cuttings.

\begin{tabular}{|lllll|}
\hline Source of variance & Dependent variable & df & F-value & P-value \\
\hline Cuttingtype & & & \\
\hline & Nb. of leaves & 2 & 1119.0 & 0.000 \\
\hline Leaves size $\left(\mathrm{cm}^{2}\right)$ & 2 & 1028.4 & 0.000 \\
\hline Cutting position & & & \\
\hline & Nb. of leaves & 2 & 3323.5 & 0.000 \\
\hline Leaves size $\left(\mathrm{cm}^{2}\right)$ & 2 & 2875.7 & 0.000 \\
\hline Nutrient solution & & & \\
\hline & 3 & 25.222 & 0.000 \\
\hline & Nb. of leaves & 3 & 80.297 & 0.000 \\
\hline Lutting type * Cutting position ${ }^{*}$ Nutrient solution & & & \\
\hline & Nb. of leaves & 12 & 01.206 & 0.275 \\
\hline Leaves size $\left(\mathrm{cm}^{2}\right)$ & 12 & 03.235 & 0.000 \\
\hline
\end{tabular}

$\mathrm{Nb} .=$ number.

2. Effect of the nutrient solution, cutting type and position on the number of sprouts and sprouts length of Argania spinosa cuttings

\subsection{Number of sprouts}

Semi-hardwood cuttings gave the best sprouting yield and produced the largest number of sprouts, followed by softwood, whereas hardwood cuttings failed to produce shoots (Table 3). Cuttings taken from the medial internodes were the ones which produced the greatest number of sprouts in comparison with the basal position, though the apical position didn't sprout at all (Table 3). In our study, analysis of variance revealed that the cuttings taken from the medial position of semi-hardwood branch treated by the QL solution produced the maximum number of sprouts $(1.81 \pm 0.13)$, followed by WPM (1.75 \pm 0.09 ) then basal softwood cuttings irrigated by HA and MS solutions $(1.31 \pm 0.11$ and $1.13 \pm 0.05$, respectively). Besides, cuttings irrigated with WPM solution were characterized by short and thin shoots, with small, narrow leaves and cuttings irrigated with MS were observed to develop more shoot tip necrosis.

\subsection{Sprouts length}

The influence of the cuttings type on sprouts length revealed that semi-hardwood cuttings performed best and produced longer shoots than softwood cuttings (Table 3). Moreover, cuttings at the middle position showed the highest shoot length values per cutting (Table 3). The results revealed that the longest sprouts were recorded on the medial position of the semi-hardwood cuttings with the use of QL $(16.88 \pm 0.6 \mathrm{~cm})$ (Figure 1), followed by the WPM solution $(16.13 \pm 0.66 \mathrm{~cm})$.

Significant differences $(P<0.05)$ existed between the mean number of sprouts and sprouts length produced by cuttings at the various stages of development and at different position on the branch of the stock plant, as well as the differences between the cuttings sprouts length produced by cuttings treated by different nutrient solutions (Table 4). Although the mean number of sprouts were not significantly $(\mathrm{p}=0.075)$ affected by nutrient solution and also there were no significant differences in term of interaction for sprouts number and length $(\mathrm{p}=$ 0.188 and $\mathrm{p}=0.179$, respectively).

Table.3: Effects of nutrient solution, cutting type and cutting position on mean values: number of sprouts (NS) and sprout length in cm (SL) of Argania spinosa cuttings.

\begin{tabular}{|c|c|c|c|c|c|c|c|}
\hline \multirow[t]{2}{*}{ Nutrient solution } & \multirow[t]{2}{*}{ Cuttingposition } & \multicolumn{2}{|l|}{ SW } & \multicolumn{2}{|l|}{ SHW } & \multicolumn{2}{|l|}{$\mathrm{HW}$} \\
\hline & & NS & SL & NS & $\mathrm{SL}$ & NS & SL \\
\hline \multirow[t]{3}{*}{$\mathrm{HA}$} & Apical & $00.00 \pm 0.00^{c}$ & $00.00 \pm 0.00^{c}$ & $00.00 \pm 0.00^{c}$ & $00.00 \pm 0.00^{\mathrm{e}}$ & $00.00 \pm 0.00$ & $00.00 \pm 0.00$ \\
\hline & Medial & $00.00 \pm 0.00^{c}$ & $00.00 \pm 0.00^{c}$ & $01.75 \pm 0.09^{\mathrm{ab}}$ & $15.31 \pm 0.62^{\mathrm{ab}}$ & $00.00 \pm 0.00$ & $00.00 \pm 0.00$ \\
\hline & Basal & $01.31 \pm 0.11^{\mathrm{ab}}$ & $11.25 \pm 0.63^{\mathrm{ab}}$ & $01.63 \pm 0.12^{\mathrm{ab}}$ & $14.56 \pm 0.61^{\mathrm{bc}}$ & $00.00 \pm 0.00$ & $00.00 \pm 0.00$ \\
\hline \multirow[t]{3}{*}{ QL } & Apical & $00.00 \pm 0.00^{c}$ & $00.00 \pm 0.00^{c}$ & $00.00 \pm 0.00^{c}$ & $00.00 \pm 0.00^{\mathrm{e}}$ & $00.00 \pm 0.00$ & $00.00 \pm 0.00$ \\
\hline & Medial & $00.00 \pm 0.00^{\mathrm{c}}$ & $00.00 \pm 0.00^{\circ}$ & $01.81 \pm 0.13^{\mathrm{a}}$ & $16.88 \pm 0.60^{\mathrm{a}}$ & $00.00 \pm 0.00$ & $00.00 \pm 0.00$ \\
\hline & Basal & $01.44 \pm 0.12^{\mathrm{a}}$ & $12.13 \pm 0.75^{\mathrm{a}}$ & $01.44 \pm 0.12^{b}$ & $15.69 \pm 0.88^{\mathrm{ab}}$ & $00.00 \pm 0.00$ & $00.00 \pm 0.00$ \\
\hline \multirow[t]{3}{*}{ WPM } & Apical & $00.00 \pm 0.00^{c}$ & $00.00 \pm 0.00^{c}$ & $00.00 \pm 0.00^{c}$ & $00.00 \pm 0.00^{\mathrm{e}}$ & $00.00 \pm 0.00$ & $00.00 \pm 0.00$ \\
\hline & Medial & $00.00 \pm 0.00^{c}$ & $00.00 \pm 0.00^{c}$ & $01.75 \pm 0.09^{\mathrm{ab}}$ & $16.13 \pm 0.66^{\mathrm{ab}}$ & $00.00 \pm 0.00$ & $00.00 \pm 0.00$ \\
\hline & Basal & $01.38 \pm 0.12^{\mathrm{a}}$ & $11.94 \pm 0.58^{\mathrm{a}}$ & $01.44 \pm 0.12^{b}$ & $15.19 \pm 0.73^{\mathrm{ab}}$ & $00.00 \pm 0.00$ & $00.00 \pm 0.00$ \\
\hline \multirow[t]{3}{*}{ MS } & Apical & $00.00 \pm 0.00^{c}$ & $00.00 \pm 0.00^{\circ}$ & $00.00 \pm 0.00^{\complement}$ & $00.00 \pm 0.00^{\mathrm{e}}$ & $00.00 \pm 0.00$ & $00.00 \pm 0.00$ \\
\hline & Medial & $00.00 \pm 0.00^{c}$ & $00.00 \pm 0.00^{\circ}$ & $01.44 \pm 0.12^{\mathrm{b}}$ & $12.88 \pm 0.66^{\mathrm{cd}}$ & $00.00 \pm 0.00$ & $00.00 \pm 0.00$ \\
\hline & Basal & $01.13 \pm 0.05^{b}$ & $10.06 \pm 0.55^{b}$ & $01.44 \pm 0.12^{b}$ & $12.18 \pm 0.76^{\mathrm{d}}$ & $00.00 \pm 0.00$ & $00.00 \pm 0.00$ \\
\hline
\end{tabular}


Within each treatments, value marked by the same letter are not significantly different (Duncan's Multiple Range Test (DMRT), $P<0.05$, mean $\pm \mathrm{SD}, \mathrm{n}=32$ ).

Table.4: Analysis of variance (ANOVA) for effect of nutrient solution, cutting type, cutting position and their interactions on the number of sprouts and sprout length ( $\mathrm{cm}$ ) of Argania spinosa cuttings.

\begin{tabular}{|lllll|}
\hline Source of variance & Dependent variable & df & F-value & P-value \\
\hline Cuttingtype & & & \\
\hline & Nb. of sprouts & 2 & 0652.9 & 0.000 \\
\hline & Sprout length $(\mathrm{cm})$ & 2 & 1235.1 & 0.000 \\
\hline Cutting position & & & \\
\hline & Nb. of sprouts & 2 & 0509.9 & 0.000 \\
\hline Sprout length (cm) & 2 & 0922.0 & 0.000 \\
\hline & & & \\
\hline & Nb. of sprouts & 3 & 02.308 & 0.075 \\
\hline Sprout length (cm) & 3 & 08.121 & 0.000 \\
\hline Cutting type * Cutting position * Nutrient solution & & & \\
\hline & Nb. of sprouts & 12 & 01.346 & 0.188 \\
\hline & Sprout length (cm) & 12 & 01.364 & 0.179 \\
\hline
\end{tabular}

$\mathrm{Nb} .=$ number.

3. Effect of the nutrient solution, cutting type and position on number of root and longest root length of the Argania spinosa cutting

\subsection{Number of roots}

The highest number of roots was produced from semihardwood cuttings, followed by softwood cuttings, while, the hardwood cuttings (which included developing leaves) failed to root completely. In addition, the cuttings from the basal part of the branch exhibited a markedly superior number of roots than medial position. However, cuttings from the apical position didn't root at all (Table 5). The greatest number of roots was obtained on cuttings sourced from the basal position of semi-hardwood which were irrigated with HA (44.63 \pm 0.69$)$ (Figure 1), followed by QL solution $(40.63 \pm 0.88)$, whereas the poorest roots number was recorded for the basal softwood cuttings irrigated with MS and WPM solutions $(31.06 \pm 0.89$ and $32.88 \pm 0.82$ ) respectively.

\subsection{Root length}

Semi-hardwood cuttings showed the longest roots, followed by softwood. Furthermore, the basal position has given the highest values, followed by the medial position (Table 5). Basal semi-hardwood cuttings treated with HA solution showed the longest roots $(28.86 \pm 0.75 \mathrm{~cm})$ (Figure 1), followed with QL $(26.19 \pm 0.68 \mathrm{~cm})$. However, the shortest roots were recorded for the basal softwood cuttings irrigated with MS and WPM solution $(22.00 \pm 0.84 \mathrm{~cm}$ and $22.38 \pm 0.56$ respectively $)$. The results indicate that nutrient solution, cutting type, cutting position has very significantly $(\mathrm{P}<0.01)$ affected both the mean number of roots and their length, while interactive effects of nutrient solution, cutting type and cutting position was significant $(\mathrm{P}<0.01)$ only for the number of roots produced (Table 6).
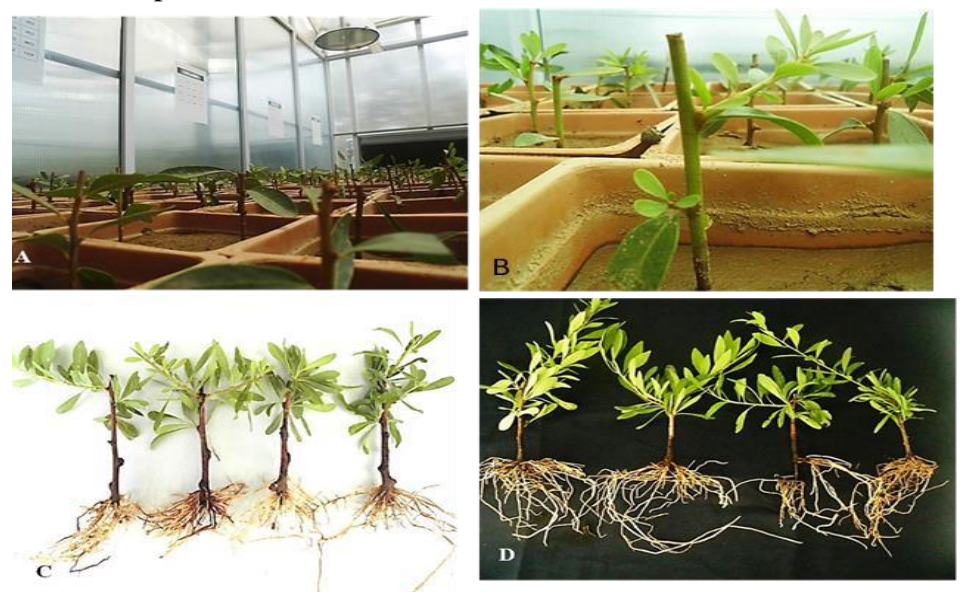

Fig. 1: (A) Argania spinosa semi-hardwood cuttings inserted in a sterilized sieved sand rooting medium, distributed according to a Randomized Complete Block Design (RCBD) under non-mist greenhouse conditions (1 week). (B) Sprouted basal leafy softwood cuttings irrigated with Quoirin and Lepoivre (QL) nutrient solution (12 weeks). (C) Rooted basal leafy semihardwood cuttings freshly removed from the sand rooting medium (48 weeks). (D) Well-developed roots of basal leafy semi-hardwood cuttings irrigated with Hoagland \& Arnon (HA) nutrient solution (72 weeks). 
Table.5: Effects of nutrient solution, cutting type and cutting position on mean values of number of roots (NR) and root length in cm (RL) of Argania spinosa cuttings.

\begin{tabular}{|c|c|c|c|c|c|c|c|}
\hline \multirow{2}{*}{$\begin{array}{l}\text { Nutrient } \\
\text { solution }\end{array}$} & \multirow{2}{*}{$\begin{array}{l}\text { Cutting } \\
\text { position }\end{array}$} & \multicolumn{2}{|l|}{ SW } & \multicolumn{2}{|l|}{ SHW } & \multicolumn{2}{|l|}{ HW } \\
\hline & & NR & RL & NR & RL & NR & RL \\
\hline \multirow[t]{3}{*}{$\mathrm{HA}$} & Apical & $00.00 \pm 0.00^{\mathrm{d}}$ & $00.00 \pm 0.00^{c}$ & $00.00 \pm 0.00^{\mathrm{f}}$ & $00.00 \pm 0.00^{\mathrm{d}}$ & $00.00 \pm 0.00$ & $00.00 \pm 0.00$ \\
\hline & Medial & $00.00 \pm 0.00^{\mathrm{d}}$ & $00.00 \pm 0.00^{\circ}$ & $40.19 \pm 0.83^{b c}$ & $26.25 \pm 0.84^{b}$ & $00.00 \pm 0.00$ & $00.00 \pm 0.00$ \\
\hline & Basal & $38.56 \pm 0.89^{\mathrm{a}}$ & $25.06 \pm 0.83^{\mathrm{a}}$ & $44.63 \pm 0.69^{\mathrm{a}}$ & $28.86 \pm 0.75^{\mathrm{a}}$ & $00.00 \pm 0.00$ & $00.00 \pm 0.00$ \\
\hline \multirow[t]{3}{*}{ QL } & Apical & $00.00 \pm 0.00^{\mathrm{d}}$ & $00.00 \pm 0.00^{c}$ & $00.00 \pm 0.00^{\mathrm{f}}$ & $00.00 \pm 0.00^{\mathrm{d}}$ & $00.00 \pm 0.00$ & $00.00 \pm 0.00$ \\
\hline & Medial & $00.00 \pm 0.00^{\mathrm{d}}$ & $00.00 \pm 0.00^{c}$ & $38.63 \pm 0.70^{\mathrm{bcd}}$ & $25.06 \pm 0.54^{\mathrm{bc}}$ & $00.00 \pm 0.00$ & $00.00 \pm 0.00$ \\
\hline & Basal & $35.38 \pm 0.88^{b}$ & $23.63 \pm 0.68^{\mathrm{ab}}$ & $40.63 \pm 0.88^{b}$ & $26.19 \pm 0.68^{b}$ & $00.00 \pm 0.00$ & $00.00 \pm 0.00$ \\
\hline \multirow[t]{3}{*}{ WPM } & Apical & $00.00 \pm 0.00^{\mathrm{d}}$ & $00.00 \pm 0.00^{c}$ & $00.00 \pm 0.00^{\mathrm{f}}$ & $00.00 \pm 0.00^{\mathrm{d}}$ & $00.00 \pm 0.00$ & $00.00 \pm 0.00$ \\
\hline & Medial & $00.00 \pm 0.00^{\mathrm{d}}$ & $00.00 \pm 0.00^{\circ}$ & $38.13 \pm 0.72^{\text {cd }}$ & $24.00 \pm 0.66^{\mathrm{bc}}$ & $00.00 \pm 0.00$ & $00.00 \pm 0.00$ \\
\hline & Basal & $32.88 \pm 0.82^{\mathrm{c}}$ & $22.38 \pm 0.56^{b}$ & $39.31 \pm 0.86^{\mathrm{bcd}}$ & $24.69 \pm 0.86^{\mathrm{bc}}$ & $00.00 \pm 0.00$ & $00.00 \pm 0.00$ \\
\hline \multirow[t]{3}{*}{ MS } & Apical & $00.00 \pm 0.00^{\mathrm{d}}$ & $00.00 \pm 0.00^{c}$ & $00.00 \pm 0.00^{\mathrm{f}}$ & $00.00 \pm 0.00^{\mathrm{d}}$ & $00.00 \pm 0.00$ & $00.00 \pm 0.00$ \\
\hline & Medial & $00.00 \pm 0.00^{\mathrm{d}}$ & $00.00 \pm 0.00^{c}$ & $35.31 \pm 0.66^{\mathrm{e}}$ & $23.19 \pm 0.81^{\mathrm{c}}$ & $00.00 \pm 0.00$ & $00.00 \pm 0.00$ \\
\hline & Basal & $31.06 \pm 0.89^{\circ}$ & $22.00 \pm 0.84^{b}$ & $37.19 \pm 0.80^{\text {de }}$ & $23.88 \pm 0.94^{\mathrm{bc}}$ & $00.00 \pm 0.00$ & $00.00 \pm 0.00$ \\
\hline
\end{tabular}

Within each treatments, value marked by the same letter are not significantly different (Duncan's Multiple Range Test $(D M R T), P<0.05$, mean $\pm S D, n=32)$.

Table.6: Analysis of variance (ANOVA) for effect of nutrient solution, cutting type, cutting position and their interactions on number of roots and root length $(\mathrm{cm})$ of Argania spinosa cuttings.

\begin{tabular}{|c|c|c|c|c|}
\hline Source of variance & Dependent variable & df & F-value & P-value \\
\hline \multicolumn{5}{|l|}{ Cuttingtype } \\
\hline & $\mathrm{Nb}$. of roots & 2 & 6186.0 & 0.000 \\
\hline & Root length (cm) & 2 & 2732.4 & 0.000 \\
\hline \multicolumn{5}{|l|}{ Cuttingposition } \\
\hline & $\mathrm{Nb}$. of roots & 2 & 5605.3 & 0.000 \\
\hline & Root length (cm) & 2 & 2582.0 & 0.000 \\
\hline \multicolumn{5}{|l|}{ Nutrient solution } \\
\hline & $\mathrm{Nb}$. of roots & 3 & 08.504 & 0.000 \\
\hline & Root length (cm) & 3 & 08.503 & 0.000 \\
\hline \multicolumn{5}{|c|}{ Cutting type $*$ Cutting position * Nutrient solution } \\
\hline & $\mathrm{Nb}$. of roots & 12 & 03.852 & 0.000 \\
\hline & Root length (cm) & 12 & 01.246 & 0.247 \\
\hline
\end{tabular}

$\mathrm{Nb} .=$ number.

4 Effect of the nutrient solution, cutting type and position on sprouting percentage, rooting percentage and survival rate of Argania spinosa cuttings

\subsection{Sprouting percentage}

Sprouting response was dependent on explants type, with a maximum sprouting being obtained through semihardwood cuttings, followed by softwood, though hardwood cuttings did not sprout at all for any of the four nutrient solutions. Moreover, medial cuttings had the highest sprouting yield, followed by cuttings of the basal position (Table 7). The highest sprouting percentage of cuttings was recorded when the medial semi-hardwood cuttings were irrigated with the QL solution (85.69 \pm $01.07 \%)$, whereas the lowest sprouting ratio was recorded on basal softwood cuttings treated by MS solution $(64.59 \pm 1.70 \%)$.

\subsection{Rooting percentage}

The semi-hardwood cuttings rooted significantly better than other cuttings type, with a higher rooting percentage (Table 7). Rooting yield varied among nodal positions, with a sequential decline in performance from basal to apical position. Basal semi-hardwood cuttings irrigated with HA produced relatively more roots $(63.81 \pm 1.89) \%$, followed by QL $(58.59 \pm 1.37) \%$, and the basal position of softwood cuttings irrigated with MS solution exhibited the lowest rooting rate $(46.09 \pm 0.68) \%$.

\subsection{Survival rate}

Semi-hardwood cuttings rooted more frequently and had lower mortality rates than softwood and hardwood 
cuttings (Table 7). The overall survival of rooted cuttings increased significantly between apical and basal positions. Indeed, basal position had the highest survival results, followed by cuttings of the medial position, whereas the cuttings from the apical position were completely decayed (Table 7). The cuttings taken from the basal position of semi-hardwood cuttings irrigated with HA solution had the highest survival rate per cutting $(96.09 \pm 0.29) \%$, followed by the QL solution $(93.75 \pm 0.39) \%$. However, basal softwood cuttings treated with MS solution had the poorest survival rate $(48.44 \pm 1.17) \%$. Some softwood cuttings irrigated with MS solution showed symptoms of apical necrosis and were unable to grow.

The analysis of variance indicates a significant difference for the mean of sprouting, rooting rate and survival percentage for each factor studied separately (nutrient solution, type and position of cuttings) ( $\mathrm{p}<$ $0.05)$, though the nutrient solution $\times$ cutting type $\times$ cutting position combinations were significant only for the survival rate (Table 8 ).

Table 7: Effects of of nutrient solution, cutting type and cutting position on mean values of sprouting percentage (SP), rooting percentage (RP), and survival rate (SR) of Argania spinosa cuttings.

\begin{tabular}{|c|c|c|c|c|c|c|c|c|c|c|}
\hline \multirow{2}{*}{$\begin{array}{l}\text { Nutrient } \\
\text { solution }\end{array}$} & \multirow{2}{*}{$\begin{array}{l}\text { Cutting } \\
\text { position }\end{array}$} & \multicolumn{3}{|l|}{ SW } & \multicolumn{3}{|l|}{ SHW } & \multicolumn{3}{|l|}{ HW } \\
\hline & & SP & $\mathrm{RP}$ & SR & SP & $\mathrm{RP}$ & SR & SP & $\mathrm{RP}$ & SR \\
\hline \multirow[t]{3}{*}{$\mathrm{HA}$} & Apical & $00.00 \pm 0.00^{c}$ & $00.00 \pm 0.00^{\circ}$ & $00.00 \pm 0.00^{\mathrm{d}}$ & $00.00 \pm 0.00^{c}$ & $00.00 \pm 0.00^{d}$ & $00.00 \pm 0.00^{\mathrm{f}}$ & $00.00 \pm 0.00$ & $00.00 \pm 0.00$ & $00.00 \pm 0.00$ \\
\hline & Medial & $00.00 \pm 0.00^{\circ}$ & $00.00 \pm 0.00^{c}$ & $00.00 \pm 0.00^{\mathrm{d}}$ & $82.66 \pm 0.87^{\mathrm{ab}}$ & $58.59 \pm 1.37 \mathrm{abc}$ & $93.75 \pm 0.39^{\mathrm{a}}$ & $00.00 \pm 0.00$ & $00.00 \pm 0.00$ & $00.00 \pm 0.00$ \\
\hline & Basal & $70.84 \pm 0.91^{\mathrm{ab}}$ & $57.81 \pm 1.56^{\mathrm{a}}$ & $74.22 \pm 0.98^{a}$ & $80.22 \pm 1.04^{\mathrm{ab}}$ & $63.81 \pm 1.89^{a}$ & $96.09 \pm 0.29^{\mathrm{a}}$ & $00.00 \pm 0.00$ & $00.00 \pm 0.00$ & $00.00 \pm 0.00$ \\
\hline \multirow[t]{3}{*}{ QL } & Apical & $00.00 \pm 0.00^{c}$ & $00.00 \pm 0.00^{c}$ & $00.00 \pm 0.00^{\mathrm{d}}$ & $00.00 \pm 0.00^{c}$ & $00.00 \pm 0.00^{\mathrm{d}}$ & $00.00 \pm 0.00^{\mathrm{f}}$ & $00.00 \pm 0.00$ & $00.00 \pm 0.00$ & $00.00 \pm 0.00$ \\
\hline & Medial & $00.00 \pm 0.00^{c}$ & $00.00 \pm 0.00^{c}$ & $00.00 \pm 0.00^{\mathrm{d}}$ & $85.69 \pm 01.07^{\mathrm{a}}$ & $57.81 \pm 1.95^{a b c}$ & $83.01 \pm 1.39^{b c}$ & $00.00 \pm 0.00$ & $00.00 \pm 0.00$ & $00.00 \pm 0.00$ \\
\hline & Basal & $76.41 \pm 1.74^{\mathrm{a}}$ & $54.69 \pm 1.37^{\mathrm{a}}$ & $71.63 \pm 1.14^{\mathrm{ab}}$ & $82.66 \pm 0.87^{\mathrm{ab}}$ & $58.59 \pm 1.37^{\mathrm{ab}}$ & $93.75 \pm 0.39^{\mathrm{ab}}$ & $00.00 \pm 0.00$ & $00.00 \pm 0.00$ & $00.00 \pm 0.00$ \\
\hline \multirow[t]{3}{*}{ WPM } & Apical & $00.00 \pm 0.00^{\circ}$ & $00.00 \pm 0.00^{\circ}$ & $00.00 \pm 0.00^{\mathrm{d}}$ & $00.00 \pm 0.00^{c}$ & $00.00 \pm 0.00^{\mathrm{d}}$ & $00.00 \pm 0.00^{\mathrm{f}}$ & $00.00 \pm 0.00$ & $00.00 \pm 0.00$ & $00.00 \pm 0.00$ \\
\hline & Medial & $00.00 \pm 0.00^{c}$ & $00.00 \pm 0.00^{c}$ & $00.00 \pm 0.00^{\mathrm{d}}$ & $83.54 \pm 0.80^{\mathrm{ab}}$ & $56.25 \pm 1.17^{\mathrm{abc}}$ & $75.10 \pm 1.21^{c}$ & $00.00 \pm 0.00$ & $00.00 \pm 0.00$ & $00.00 \pm 0.00$ \\
\hline & Basal & $74.50 \pm 0.58^{\mathrm{a}}$ & $53.91 \pm 1.37^{\mathrm{a}}$ & $67.97 \pm 0.98^{b}$ & $79.54 \pm 1.17^{\mathrm{ab}}$ & $57.81 \pm 0.87^{\mathrm{abc}}$ & $77.98 \pm 1.26^{c}$ & $00.00 \pm 0.00$ & $00.00 \pm 0.00$ & $00.00 \pm 0.00$ \\
\hline \multirow[t]{3}{*}{ MS } & Apical & $00.00 \pm 0.00^{\circ}$ & $00.00 \pm 0.00^{\circ}$ & $00.00 \pm 0.00^{\mathrm{d}}$ & $00.00 \pm 0.00^{c}$ & $00.00 \pm 0.00^{d}$ & $00.00 \pm 0.00^{\mathrm{f}}$ & $00.00 \pm 0.00$ & $00.00 \pm 0.00$ & $00.00 \pm 0.00$ \\
\hline & Medial & $00.00 \pm 0.00^{\mathrm{c}}$ & $00.00 \pm 0.00^{c}$ & $00.00 \pm 0.00^{\mathrm{d}}$ & $78.66 \pm 1.43^{\mathrm{ab}}$ & $47.66 \pm 1.46^{c}$ & $53.91 \pm 1.37^{\mathrm{e}}$ & $00.00 \pm 0.00$ & $00.00 \pm 0.00$ & $00.00 \pm 0.00$ \\
\hline & Basal & $64.59 \pm 1.70^{b}$ & $46.09 \pm 0.68^{b}$ & $48.44 \pm 1.17^{\circ}$ & $76.31 \pm 1.50^{b}$ & $50.78 \pm 1.76 b^{c}$ & $64.06 \pm 1.17^{\mathrm{d}}$ & $00.00 \pm 0.00$ & $00.00 \pm 0.00$ & $00.00 \pm 0.00$ \\
\hline
\end{tabular}

Within each treatments, value marked by the same letter are not significantly different (Duncan's Multiple Range Test $(D M R T), P<0.05$, mean $\pm S D, n=32)$.

Table.8: Analysis of variance (ANOVA) for effect of nutrient solution, cutting type, cutting position and their interactions on sprouting percentage, rooting percentage, and survival rate of Argania spinosa cuttings.

\begin{tabular}{|lllll|}
\hline Source of variance & Dependent variable & df & F-value & P-value \\
\hline Cutting type & & & \\
\hline & Sprouting percent & 2 & 2254.1 & 0.000 \\
\hline & Rootingpercent & 2 & 0733.9 & 0.000 \\
\hline & Survival percent & 2 & 2264.3 & 0.000 \\
\hline Cutting position & & & \\
\hline & Sprouting percent & 2 & 1954.2 & 0.000 \\
\hline & Rooting percent & 2 & 0708.0 & 0.000 \\
\hline & Survival percent & 2 & 2058.4 & 0.000 \\
\hline Nutrient solution & & & \\
\hline & & 3 & 03.325 & 0.022 \\
\hline & Sprouting percent & 3 & 04.601 & 0.005 \\
\hline Rooting percent & 3 & 55.811 & 0.000 \\
\hline Cutting type * Cutting position * Nutrient solution & & & \\
\hline & Sprouting percent & 12 & 00.849 & 0.601 \\
\hline & Rooting percent & 12 & 00.746 & 0.703 \\
\hline & Survival percent & 12 & 10.690 & 0.000 \\
\hline
\end{tabular}




\section{DISCUSSION}

The present results indicate a significant effect of cutting type on the success of sprouting, rooting and survival rates for A. spinosa cuttings. Vegetative propagation of argan trees can best be achieved using semi-hardwood cuttings followed by softwood cuttings. The findings from this study for high sprouting and rooting ability of semi-hardwood cuttings are in accordance with results obtained for other tree species, such as Moringa oleifera, where semi-hardwood and hardwood cuttings performed best and produced the highest number of shoots and the longest shoots, while the shortest shoots were produced on softwood cuttings (Antwi-Boasiako and Enninful, 2011); Stevia rebaudiana, where semi-hardwood cuttings were more successfulthan softwood cuttings (Abdullateef and Osman, 2012); Duranta repens, for which semihardwood and hardwood cuttings rooted significantly better than softwood cuttings with a higher percentage of rooted cuttings, a greater number of roots and longer roots length per rooted cutting (Okunlola, 2013); Bougainvillea glabra, in which root number was higher for semihardwood compared with softwood cuttings (Seyedi et al. 2014). Semi-hardwood cuttings are generally considered easy to propagate due to its low production of secondary metabolites in comparison with hardwood cuttings (Hartmann et al. 1997).

In addition, the hardwood cuttings prepared had no leaves, therefore their dependence on photosynthetic activity for rooting and bud formation was denied, which adversely influenced their sprouting, rooting and survival efficiency. This lack of sprouting and rooting performance of hardwood cuttings could also be pronounced by the early appearance of leaves which could lead to resource depletion before rooting (AntwiBoasiako and Enninful, 2011). Moreover, this increase in rooting potential of semi-hardwood cuttings may be due to their lignification, which increases their ability to withstand dry or other adverse conditions. Therefore, they survived in moist soil until the roots formed, whereas softwood cuttings are delicate, dried-out rapidly and much more subject to attacks by various fungal diseases (Longman, 1993). In fact, the maintenance or presence of leaves on semi-hardwood and softwood cuttings influenced sprouting and rooting due to their ability to produce auxins and carbohydrates (Hartmann et al., 1990).

The analysis of variance indicated that significant differences existed in terms of sprouting and rooting ability of A. spinosa cuttings taken from different cutting positions of stock plants shoots. The highest root number, root length, rooting percentage and survival rate was observed in cuttings taken from a basal position, followed by those taken from a medial cutting position. However, the cuttings made from an apical position hadn't rooted at all. The observations showed that rooting response of $A$. spinosa is a function of nodal position and the cuttings rooted better if taken from a basal position of the stock plant. These results are in agreement with those obtained previously for other tree species such as Azadirachta indica (Palanisamy and Kumar, 1997), Rosa hybrida (Bredmose et al., 2004; Otiende et al., 2017), Dalbergia sissoo (Husen, 2004), Ulmus villosa (Bhardwaj and Mishra, 2005), Tectona grandis (Husen and Pal, 2007), Dalbergia melanoxylon (Amri et al., 2010) and Pterocarpus santalinoides (Ky-Dembele et al., 2016). Better rooting of cuttings made from basal position followed by cuttings from middle position then from an apical position. This may be associated with certain environmental factors such as luminous intensity, photoperiod, temperature (Hansen, 1986) or by changes in the extent of lignification and the degree of secondary thickening along the stem (Girouard, 1969; Hartmann et al., 1997). There are also physiological and anatomical factors which may influence the performance of cuttings from different nodal positions such as leaf water potential, leaf age, stomatal distribution, stem diameter, wood structure and xylem elements (Hartmann and Kester, 1990). These factors could influence the distribution of available mineral nutrients, endogenous growth regulators and carbohydrates in both the mother plant and the cuttings sampled (Leakey and Coutts, 1989). Leakey (1983) stated that the poor rooting of apical cuttings may be due to less favorable water relations and increased susceptibility to water stress in young cuttings. Otherwise, this may be due either to an inhibitory effect of auxins produced during root initiation (Smith and Wareing, 1972) or to low carbohydrate concentrations in the apical portion (Palanisamy and Kumar, 1997). 
Table.9: Ion concentrations of nutrient solutions (Hoagland and Arnon (HA), Quoirin and Lepoivre (QL), Murashige and Skoog (MS), and Woody Plant Medium (WPM)).

\begin{tabular}{|c|c|c|c|c|}
\hline \multirow[b]{2}{*}{ Macronutrients (mM) } & \multicolumn{4}{|c|}{ Nutrient solution } \\
\hline & $\mathrm{HA}$ & $\mathrm{QL}$ & WPM & MS \\
\hline $\mathrm{NH}_{4}^{+}$ & 02.0 & 05.0 & 05.0 & 20.6 \\
\hline NO3- & 14.0 & 33.0 & 09.7 & 39.4 \\
\hline $\mathrm{PO}^{-}$ & 02.0 & 02.0 & 01.3 & 01.3 \\
\hline $\mathrm{K}^{+}$ & 06.0 & 19.8 & 12.6 & 20.0 \\
\hline $\mathrm{Ca}^{+}$ & 04.0 & 05.1 & 03.0 & 03.0 \\
\hline $\mathrm{Mg}^{+}$ & 01.0 & 01.5 & 01.5 & 01.5 \\
\hline $\mathrm{SO}^{-}$ & 01.0 & 01.6 & 07.2 & 01.7 \\
\hline \multicolumn{5}{|l|}{ Micronutrients $(\mu \mathrm{M})$} \\
\hline $\mathrm{Fe}^{++}$ & 64.0 & 100.0 & 100.0 & 100.0 \\
\hline $\mathrm{Zn}^{++}$ & 02.0 & 29.9 & 29.9 & 29.9 \\
\hline $\mathrm{Cu}^{++}$ & 00.5 & 01.0 & 01.0 & 01.0 \\
\hline $\mathrm{B}^{+++}$ & 25.0 & 100.0 & 100.0 & 100.0 \\
\hline $\mathrm{Mn}^{++}$ & 02.0 & 44.8 & 132.0 & 100.0 \\
\hline $\mathrm{MoO4}^{-}$ & 00.5 & 01.0 & 01.0 & 01.0 \\
\hline $\mathrm{I}^{-}$ & - & 00.5 & - & 05.0 \\
\hline $\mathrm{Co}^{++}$ & - & 00.1 & - & 00.1 \\
\hline $\mathrm{Cl}^{-}$ & 50.0 & - & 01.3 & 06.0 \\
\hline $\mathrm{Na}^{+}$ & 64.0 & 200.0 & 200.0 & 200.0 \\
\hline \multicolumn{5}{|l|}{ Summary values (mM) } \\
\hline TotalN & 16.0 & 38.0 & 14.7 & 60.0 \\
\hline $\mathrm{NO}^{-}-\mathrm{NH}_{4}{ }^{+}$ & 07.0 & 06.6 & 02.0 & 01.9 \\
\hline Total Molarity & 30.2 & 68.5 & 42.2 & 94.0 \\
\hline
\end{tabular}

Finally, there was a significant difference between the four nutrient solutions studied. The results presented herein indicate that MS and WPM media were superior to HA and QL for the number of leaves and leaf size. The sprouting percentage, the number of shoots and shoot length on QL and WPM media might be preferred to the one on HA and MS, while HA and QL were superior to WPM and MS for survival rate, rooting percentage, number of adventitious roots and their elongation. A number of studies have pointed out that nutrient uptake is closely related to the sprouting and rooting proprieties: Blomstedt et al. (1991) found that root proliferation of Eucalyptus regnans was greater by using HA or WPM in comparison with MS. Wang (1991) also observed a higher degree of multiple shoot formation of Prunus communis explants on WPM and QL than on MS. However, Abousalim and Mantell (1994) indicated that the shoot-tip necrosis is a frequent and persistent problem in shoot cultures of Pistacia vera, by adding a standard
MS solution. Pérez-Tornero and Burgos (2000) reported also that WPM produced chloros is in the leaves of Prunus armeniaca. The differences observed among these nutrient solutions could be explained by their total ionic strength. Indeed, HA solution has a total ion concentration equivalent to $32 \%$ of MS, WPM $45 \%$ and QL is $73 \% \mathrm{MS}$ (Table 9). In fact, plants growing on a concentrated nutrient solution developed a short, compact, and densely branched root system, while on dilute solutions or water the roots were long and more sparsely branched (Forde and Lorenzo, 2001). This increase in the level of mineral nutrition benefits the shoot rather more than the root, whereas nutrient deficiency often induces an increased root/shoot ratio (Chapin, 1980). Otherwise, after separation from the stock plant, cuttings have a fixed mineral nutrient pool. The mineral nutrient pool in the cutting may even decline as a result of leaching during propagation (Blazich et al., 1983). Therefore, the low rooting and survival percentages of MS solution may be 
explained by its excessive nitrogen content for the $A$. spinosa cuttings, while the leaves chlorosis of WPM solution could be due to its low nitrogen content. The fullstrength MS is high in ammonium $(20.6 \mathrm{mM})$ and nitrate ions $(39.4 \mathrm{mM})$ followed by QL and WPM $(5 \mathrm{mM})$, whereas HA is a solution with the lowest ammonium content $(2 \mathrm{mM})$. Macronutrients of HA contain a $\mathrm{NO}^{-} / \mathrm{NH}^{+}$ratio (7) much higher than the other nutrient solutions. However, MS has the lowest $\mathrm{NO}^{-} / \mathrm{NH}^{+}$ratio (1.9). High endogenous nitrogen levels in cuttings seem to enhance shoot growth if the level of nitrogen exceeds the optimum for root primordium initiation and development (Brouwer, 1962). Furthermore, the decrease in rooting potential of A. spinosa cuttings due to an increased nitrogen supply in MS solution may be due to a decrease in the processes of carbon assimilation and partitioning (Druege et al., 2000). Basu and Ghosh (1974) reported that the rooting cofactor activity was inversely related to nitrogen supply. High ratios of total available carbohydrates/total nitrogen $(\mathrm{C} / \mathrm{N})$ and total phosphorus/total nitrogen $(\mathrm{P} / \mathrm{N})$ increased anthocyanin pigmentation in the shoot induced an increased rooting cofactor activity in the cuttings tissues. Our observations indicated that MS and WPM produced shoot-tip necrosis, shoot hyperhydricity and the lowest rooting percentage and survival rate. This observed responses may be due to the slightly low calcium contents of WPM and MS (3 mg) in comparison with HA (4 mg) and QL (5 mg) (Table 9). Indeed, the low availability of calcium may influence rooting because the endogenous pool of these minerals is poorly transported in the phloem (Eliasson, 1978). Moreover, It has been shown to act as a secondary messenger at the crosstalk of auxin and nitric oxide signaling pathways of adventitious roots formation (Lanteri et al., 2006), to be involved in cell division and root primordia elongation process (Burstrom, 1968; Imaseki, 1985).

\section{CONCLUSION}

The results of this study revealed that sprouting and rooting success of Argania spinosa cuttings were significantly influenced by nutrient solution, cutting type and nodal position. The hardwood cuttings taken from the basal position with MS solution gave the best number of leaves (36.25) and leaves size $\left(28.93 \mathrm{~cm}^{2}\right)$. The highest number of sprouts $(1.81)$, sprouts length $(16.88 \mathrm{~cm})$ and sprouting percentage $(85.69 \%)$ were recorded in leafy semi-hardwood cuttings from medial position and treated by QL solution. The leafy semi-hardwood cuttings taken from basal position and irrigated with Hoagland solution produced in average more roots (44.63), longer roots $(28.86 \mathrm{~cm})$, and had higher rooting and survival percentages: $63.81 \%$ and $96.09 \%$, respectively. The results of the present study clearly indicated that the cuttings from adult A. spinosa trees can be propagated using basal semi-hardwood cuttings receiving Hoagland nutrient solution. Further work could focus on the needs of each nutrient for A. spinosa cuttings to produce high quality materials for planting argan orchards and promoting sustainable arganiculture programs.

\section{ACKNOWLEDGEMENTS}

Some of the work is done within the project supported by the Wallonia-Brussels Federation through its cooperation office in Rabat, Morocco. We are grateful to our colleagues of the Department of Life Sciences, Bioengineering Unit, (CRA-W), for their support for A. Benbya PhD during the two internships training in (CRAW) at Gembloux, Belgium.

\section{REFERENCES}

[1] Emberger, L. (1925). Le domaine naturel de l'arganier. Bulletin de la Société Botanique de France, 72(4), 770-774. doi:10.1080/00378941.1925.10832788

[2] Msanda, F. (1993). Ecologie et cartographie des groupements végétaux d'Anzi (Anti-Atlas occidental, Maroc) et contribution à l'étude de la diversité génétique de l'arganier (Argania spinosa (L.) Skeels) (Doctoral dissertation, Grenoble 1).

[3] Msanda, F., El Aboudi, A., and Peltier, J. P. (2005). Biodiversité et biogéographie de l'arganeraie marocaine. Cahiers Agricultures, 14(4), 357-364.

[4] Morton, J. F., and Voss, G. L. (1987). The argan tree (Argania sideroxylon, Sapotaceae), a desert source of edible oil. Economic Botany, 41(2), 221-233. doi: 10.1007/BF02858970.

[5] M'hirit, O., Benzyane, M., Benchekroune, F, El Yousfi, S.M. and Bendaanoun, M. (1998). L'Arganier: Une espèce fruitière-forestière a usages multiples. Ed. Pierre Mardaga, Sprimont, Belgique. $150 \mathrm{p}$.

[6] Nouaim, R., Mangin, G., Breuil, M. C., and Chaussod, R. (2002). The argan tree (Argania spinosa) in Morocco: Propagation by seeds, cuttings and in-vitro techniques. Agroforestry Systems, 54(1), 71-81.doi: 10.1023/A:1014236025396.

[7] Hartmann, H. T., Kester, D. E., Davies, F. T., and Geneve, R. L. (1997). Plant propagation: principles and practices (6th edition, pp 770). Prentice-Hall Incorporated. New Jersey.

[8] Leakey, R. R. B., (2004). Physiology of vegetative reproduction. In: Burley, Jeffrey, Evans, Julian, and Youngquist, J. A. (eds) Encyclopaedia of Forest Sciences (1st edition, pp. 1655-1668). Academic Press, London.

[9] De Vries, D. P., and Dubois, L. A. (1988). The effect of BAP and IBA on sprouting and adventitious root formation of Amanda rose single-node softwood 
cuttings. Scientia Horticulturae, 34(1-2), 115-121. doi : 10.1016/0304-4238(88)90081-7.

[10] Dubois, L. A., and De Vries, D. P. (1991). Variation in adventitious root formation of softwood cuttings of Rosa chinensis minima (Sims) Voss cultivars. Scientia Horticulturae, 47(3-4), 345-349. doi: 10.1016/0304-4238(91)90018-T.

[11] De Klerk, G. J., Van Der Krieken, W., and de Jong, J. C. (1999). Review the formation of adventitious roots: new concepts, new possibilities. In Vitro Cellular and Developmental Biology Plant, 35(3), 189-199. doi: 10.1007/s11627-999-0076-z

[12] Németh, G. (1986). Induction of rooting. In Trees (Volume 1, pp. 49-64). Springer, Berlin, Heidelberg.

[13] Hartmann, H. T., Kester, D. E., Davies, F. T., and Geneve, R. L. (2002). Plant propagation: principles and practices (7th edition, pp. 880). Prentice-Hall Incorporated, Upper Saddle River, New Jersey.

[14] Greenwood, M. S., and Hutchison, K. W. (1993). Maturation as a developmental process. In Clonal Forestry (Volume 1, pp. 14-33). Springer, Berlin, Heidelberg.

[15] Hansen, J., and Kristensen, K. (1990). Axillary bud growth in relation to adventitious root formation in cuttings. Physiologia Plantarum, 79(1), 39-44. doi:10.1111/j.1399-3054.1990.tb05863.x

[16] Bredmose, N., Kristiansen, K., and Nielsen, B. (2004). Propagation temperature, PPFD, auxin treatment, cutting size and cutting position affect root formation, axillary bud growth and shoot development in miniature rose (Rosa hybrida L.) plants and alter homogeneity. The Journal of Horticultural Science and Biotechnology, 79(3), 458-465. doi:10.1080/14620316.2004.11511790.

[17] Bredmose, N., and Hansen, J. (1996). Topophysis affects the potential of axillary bud growth, fresh biomass accumulation and specific fresh weight in single-stem roses (Rosa hybrida L.). Annals of Botany, 78(2), 215-222. doi:10.1006/anbo.1996.0115

[18] Husen, A., and Pal, M. (2007). Effect of branch position and auxin treatment on clonal propagation of Tectona grandis Linn. f. New Forests, 34(3), 223233. doi: 10.1007/s 11056-007-9050-y.

[19] Otiende, M. A., Nyabundi, J. O., Ngamau, K., and Opala, P. (2017). Effects of cutting position of rose rootstock cultivars on rooting and its relationship with mineral nutrient content and endogenous carbohydrates. Scientia Horticulturae, 225(1), 204212. doi: 10.1016/j.scienta.2017.07.009

[20] Fageria, N. K., and Moreira, A. (2011). The role of mineral nutrition on root growth of crop plants. In Advances in agronomy (Volume 110, pp. 251-331). Elsevier Inc. Academic Press.
[21] Haissig B.E. (1986). Metabolic processes in adventitious rooting of cuttings. In: Jackson M.B. (eds) New Root Formation in Plants and Cuttings. Developments in Plant and Soil Sciences (Volume 20, pp 141-189). Springer, Dordrecht.

[22] Eliasson, L. (1978). Effects of nutrients and light on growth and root formation in Pisum sativum cuttings. Physiologia Plantarum, 43(1), 13-18. doi: 10.1111/j.1399-3054.1978.tb01560.x.

[23] Hoagland, D. R., and Arnon, D. I. (1950). The waterculture method for growing plants without soil (2nd edition, pp. 347). Circular. California Agricultural Experiment Station.

[24] Quoirin, M., and Lepoivre, P. H. (1977). Improved media for in vitro culture of Prunus sp. In Symposium on Tissue Culture for Horticultural Purposes, 78, 437-442. doi10.17660/ActaHortic. 1977.78.54.

[25] Murashige, T., and Skoog, F. (1962). A revised medium for rapid growth and bio assays with tobacco tissue cultures. Physiologia Plantarum, 15(3), 473-497. doi: $\quad 10.1111 /$ j.13993054.1962.tb08052.x.

[26] Lloyd, G., and McCown, B. (1980). Commerciallyfeasible micropropagation of mountain laurel Kalmia latifolia, by use shoot-tip culture. Combined Proceedings of the International Plant Propagation Society, 30, 421-427.

[27] Antwi-Boasiako, C., and Enninful, R. (2011). Effects of growth medium, a hormone, and stem-cutting maturity and length on sprouting in Moringa oleifera Lam. The Journal of Horticultural Science and Biotechnology, 866(6), 619-625. doi:10.1080/14620316.2011.11512813

[28] Abdullateef, R. A., and Osman, M. (2012). Effects of stem cutting types, position and hormonal factors on rooting in Stevia rebaudiana Bertoni. Journal of Agricultural Science, 4(1), 49 . doi: 10.5539/jas.v4n 1p49.

[29] Okunlola, A. I. (2013). The effects of cutting types and length on rooting of Duranta Repens in the nursery. Global Journal of Human-Social Science Research, 13(3), 1-4. https://socialscienceresearch.org/index.php/GJHSS/a rticle/view/774.

[30] Seyedi, A., Esmaeili, A., Zadeh, K., and Posiabidi, M. (2014). Comparative evaluation of the rooting in cuttings in (Bougainvillea glabra L.). International Journal of Farming and Allied Sciences, 3(8), 872875.

[31] Longman, K. A. (1993). Tropical trees: propagation and planting manuals. In Rooting cuttings of tropical trees (Volume 1, pp. 137). Common wealth Science Council. 
[32] Hartmann, H. T., Kester, D. E. and Davis, T. F. (1990). Plant Propagation. Principles and Practices (5th edition, pp. 647). Prentice-Hall Incorporated. Englewood Cliffs, New Jersey.

[33] Palanisamy, K., and Kumar, P. (1997). Effect of position, size of cuttings and environmental factors on adventitious rooting in neem (Azadirachta indica A. Juss). Forest Ecology and Management, 98(3), 277-280. doi:10.1016/S0378-1127(97)00116-3

[34] Husen, A. (2004). Clonal propagation of Dalbergia sissoo Roxb. by softwood nodal cuttings: effects of genotypes, application of IBA and position of cuttings on shoots. Silvae Genetica, 53(1-6), 50-55. doi: 10.1515/sg-2004-0009.

[35] Bhardwaj, D. R., and Mishra, V. K. (2005). Vegetative propagation of Ulmus villosa: effects of plant growth regulators, collection time, type of donor and position of shoot on adventitious root formation in stem cuttings. New Forests, 29(2), 105116. doi:10.1007/s 11056-005-0240-1.

[36] Amri, E., Lyaruu, H. V. M., Nyomora, A. S., and Kanyeka, Z. L. (2010). Vegetative propagation of African Blackwood (Dalbergia melanoxylon Guill. and Perr.): effects of age of donor plant, IBA treatment and cutting position on rooting ability of stem cuttings. New Forests, 39(2), 183-194. doi: 10.1007/s 11056-009-9163-6

[37] Ky-Dembele, C., Bayala, J., Kalinganire, A., Traoré, F. T., Koné, B., and Olivier, A. (2016). Clonal propagation of Pterocarpus santalinoides L'Hér. ex DC.: the effect of substrate, cutting type, genotype and auxin. Southern Forests: Journal of Forest Science, 78(3), 193-199. doi: 10.2989/20702620.2016.1150696.

[38] Hansen, J. (1986). Influence of cutting position and stem length on rooting of leaf-bud cuttings of Schefflera arboricola. Scientia Horticulturae, 28(12), 177-186. doi: 10.1016/0304-4238(86)90137-8

[39] Girouard, R. M. (1969). Physiological and biochemical studies of adventitious root formation. Extractible rooting cofactors from Hedera helix. Canadian Journal of Botany, 47(5), 687-699. doi.org/10.1139/b69-098.

[40] Leakey, R. R. B., and Coutts, M. P. (1989). The dynamics of rooting in Triplochiton scleroxylon cuttings: their relation to leaf area, node position, dry weight accumulation, leaf water potential and carbohydrate composition. Tree Physiology, 5(1), 135-146. doi: 10.1093/treephys/5.1.135.

[41] Leakey, R. R. B. (1983). Stockplant factors affecting root initiation in cuttings of Triplochiton scleroxylon K. Schum., an indigenous hardwood of West Africa. Journal of Horticultural science, 58(2), 277-290. doi :10.1080/00221589.1983.11515121.
[42] Smith, N. G., and Wareing, P. F. (1972). The distribution of latent root primordia in stems of Populus robusta, and factors affecting the emergence of preformed roots from cuttings. Forestry: An International Journal of Forest Research, 45(2), 197209. doi:10.1093/forestry/45.2.197.

[43] Blomstedt, C., Cameron, J., Whiteman, P., and Chandler, S. F. (1991). Micropropagation of juvenile Eucalyptus regnans (mountain ash). Australian Journal of Botany, 39(2), 179-186. doi: 10.1071/BT9910179.

[44] Wang, Q. (1991). Shoot multiplication of pear in double-phase medium culture. In International Symposium on Plant Biotechnology and its Contribution to Plant Development, Multiplication and Improvement, 289, 349-350. doi:10.17660/ActaHortic. 1991.289.90

[45] Abousalim, A., and Mantell, S. H. (1994). A practical method for alleviating shoot-tip necrosis symptoms in in vitro shoot cultures of Pistacia vera cv. Mateur. Journal of Horticultural Science, 69(2), 357-365. doi:10.1080/14620316.1994.11516465.

[46] Pérez-Tornero, O., and Burgos, L. (2000). Different media requirements for micropropagation of apricot cultivars. Plant Cell, Tissue and Organ Culture, 63(2), 133. doi.10.1023/A:1006430718024

[47] Forde, B., and Lorenzo, H. (2001). The nutritional control of root development. Plant and Soil, 232(12), 51-68. doi:10.1023/A:1010329902165.

[48] Chapin, F. S. (1980). The mineral nutrition of wild plants. Annual Review of Ecology and Systematics, 11(1), 233-260. doi: 10.1146/annurev.es.11.110180.001313.

[49] Blazich, F. A., Wright, R. D., and Schaffer, H. E. (1983). Mineral nutrient status of Convexa holly cuttings during intermittent mist propagation as influenced by exogenous auxin application. JournalAmerican Society for Horticultural Science, 108, 425-429.

[50] Brouwer, R. (1962). Nutritive influences on the distribution of dry matter in the plant. Nutritive influences on the distribution of dry matter in the plant. Instituut Voor Biologisch en Scheikundig Onderzoek Van Land Bouwgewassen, (205), 20p.

[51] Druege, U., Zerche, S., Kadner, R., and Ernst, M. (2000). Relation between nitrogen status, carbohydrate distribution and subsequent rooting of chrysanthemum cuttings as affected by pre-harvest nitrogen supply and cold-storage. Annals of Botany, 85(5), 687-701. doi: 10.1006/anbo.2000.1132.

[52] Basu, R. N., and Ghosh, S. K. (1974). Effect of nitrogen nutrition of stock plants of Justicia gendarussa L. on the rooting of cuttings. Journal of 
Horticultural Science, 49(3), 245-252. doi:10.1080/00221589.1974.11514576.

[53] Lanteri, M. L., Pagnussat, G. C., and Lamattina, L. (2006). Calcium and calcium-dependent protein kinases are involved in nitric oxide-and auxininduced adventitious root formation in cucumber. Journal of Experimental Botany, 57(6), 1341-1351. doi:10.1093/jxb/erj109.

[54]Burstrom, H. G. (1968). Calcium and plant growth. Biological Reviews, 43(3), 287-316. doi.10.1111/j.1469185X.1968.tb00962.x.

[55] Imaseki, H. (1985). Hormonal control of woundinduced responses. In Hormonal regulation of development (3rd edition, pp. 485-512). Springer, Berlin, Heidelberg. 